Article

\title{
Possession and Precedence: Juxtaposing Customary and Legal Events to Establish Land Authority
}

\author{
Laura S. Meitzner Yoder ${ }^{1, *}$ and Sandra F. Joireman ${ }^{2}$ \\ 1 Program in Human Needs and Global Resources and Department of Environmental Science, \\ Wheaton College, Wheaton, IL 60187, USA \\ 2 Department of Political Science, University of Richmond, Richmond, VA 23173, USA \\ * Correspondence: laura.yoder@wheaton.edu
}

Received: 30 June 2019; Accepted: 7 August 2019; Published: 18 August 2019

\begin{abstract}
Land restitution carries implicit recognition of some previous claim to ownership, but when are first claims recognized? The concepts of first possession and original acquisition have long been used as entry points to Western concepts of property. For Austronesia, the concept of precedence is used in customary systems to justify and describe land claims and Indigenous authority. Conflict and political change in Timor-Leste have highlighted the co-existence of multiple understandings of land claims and their legitimacy. Considering customary principles of precedence brings into relief important elements of first possession important in land restitution processes. This paper juxtaposes the concept of original acquisition in property theory to two different examples of original claims from Timor-Leste: a two-part customary origin narrative from Oecusse and the development of a national land law for the new state. In these three narratives, we identify three different establishment events from which land authority develops. The article then uses this idea of the establishment event to explore five points of customary-statutory intersection evident from the land restitution process: (1) legitimate sources of land authority; (2) arbitrary establishment dates; (3) privileging of social order; (4) recognition of spiritual ties to land; and (5) the possibility for reversal.
\end{abstract}

Keywords: land restitution; first possession; precedence; customary land; customary authority; Timor-Leste; Austronesia; Southeast Asia

\section{Introduction: Authorities' Legitimacy in Land Restitution}

Land restitution can occur where parties acknowledge that a past allocation or occupation of land was not legitimate. Norms of legitimacy change over time and with changing political circumstances. Restitution seeks to tangibly redress past loss or harm (of forced displacement, resource theft, colonialism, assimilation, etc.) that is not accepted as legitimate in the current historical moment. Restitution rests on the recognized legitimacy of current authorities and their presumed superiority to past actors and actions. In moments of significant sociopolitical change-resulting from conflict, regime change, economic transformation, or other factors-which authorities are recognized as legitimate adjudicators to determine land ownership at various scales? Where multiple legal systems have operated in succession, which will persist or receive official recognition? Where customary and statutory systems coexist, where and which will continue to be actively used with respect to land ownership, both de jure and de facto? How are landholding preferences, priorities, and practices of Indigenous rural communities selectively recognized within state processes?

This paper juxtaposes the Western property concept of original acquisition for first possession and the Austronesian concept of precedence. Both "provide a baseline point of reference for calculating priority in relation to land" ([1] p. 138) or what we articulate here as an establishment event. We examine them in tandem because concepts of land restitution by their nature challenge or rearticulate 
the establishment event and decision-making authority with respect to land. In addition, viewing them together reminds us of certain characteristics of first possession that can be obscured in a more dichotomous discussion of customary versus statutory property claims.

The paper opens with an initial framing discussion of first possession and original occupation in formal legal contexts, followed by a description of precedence (Sections 3-5). Then, we examine two disparate situations from Timor-Leste that illustrate who has authority to determine legitimate norms for land claims and ownership. The first (Section 6) is a two-part narrative on establishing Indigenous land authorities in a rural area, which highlights the Austronesian concept of precedence and ideas of legitimate first possession/establishment events in that context. The second (Section 7), concerns the fifteen-year process of drafting and approving a national land law for Timor-Leste. In this case, civil society offered sustained contestation over the legitimacy of customary and state authority to define land ownership in a context where there were substantively different understandings of "first possession". Ironically, the land law itself was an establishment event as the primary land law of the new state of Timor-Leste. In Section 8, we reflect on the above cases to consider what customary practices of precedence bring into relief regarding the Western concept of first possession, focusing on five relevant areas of intersection.

\section{Materials and Methods}

This paper is based on ongoing ethnographic work which the corresponding author began in 2001 on claims to land and authority in Timor-Leste, literature review, and analysis of international legal principles and policies. Based in the Oecusse-Ambeno enclave from 2002-2004 with return visits in 2005 and near annually from 2011-19 to follow new developments, author Meitzner Yoder has pursued an ethnography of government officials' and customary authorities' interaction around land and forest management authority in the emerging local and national context. This work involved accompanying land dispute resolution processes; meeting with customary authorities in every administrative village of Oecusse; attending ceremonies in which state officials recognized customary figures' authority to manage discrete land domains; and participating in everyday life in the largely agrarian enclave during the years immediately surrounding full independence. Subsequent work has focused on the recent mega development projects and administrative rearrangements in the enclave. Customary figures from the Oecusse highlands with inherited authority to speak about origins and land repeatedly recounted the narratives included in this paper to me with other villagers present in 2003. These narrative excerpts are not deemed secret knowledge and are commonly known among (even if not spoken by) residents of the administrative village. The literature review for international legal principles and policies addressed those sources most relevant to establishment events, such as colonization, as well as international policy pertaining to land restitution.

\section{Possession and First Occupation in Western Property Theory and International Law}

The concept of first possession posits that those recognized as first claimants in an establishment event have stronger claims to land than later arrivals or claimants. Many early Western social theorists used first possession and occupation as an entry point to discussions about property. Both John Locke [2] and Adam Smith [3] saw first occupation or possession as critical to establishing any sort of right to property. For Locke, that first possession famously comes from not just a claim but from the input of one's visible labor on the land, making it productive and rewarded with ownership. David Hume also viewed first possession as necessary for the claim of property, but his idea about the purpose of property sees it as necessary for the regulation of behavior rather than as a foundation for the political community [4].

Europeans developed the 'law of territory' with colonization (by both civil- and common-law countries) to justify claims to foreign territory. Articulated as terra nullius or sometimes 'original acquisition,' the fundamental idea was that before colonization there were no recognized prior rights to the territory, and it could be thus claimed and occupied by the colonizing power-an establishment 
event. "Such appropriation of territory was always considered justified because the occupation of terra nullius comprised an original title, which was legitimate in origin, requiring no will from a transferor" ([5] p. 715). From the original claim, established by the colonizer, a chain of titles could be established providing the foundation for a system of transferable property rights. In Australia, terra nullius was used to justify British claims to the territory, even though it was not used in other British colonial contexts and the British were well aware of the Indigenous population [6]. Huh (2015) notes that after decolonization, the use of terra nullius fell out of usage in favor of 'original title', although the practical meaning was similar. At present, it is increasingly accepted that there was little originality in the idea of original acquisition, used to claim territory through colonization. Instead, there is a recognition, not just of Indigenous claims to land, but that the nature of those claims is related to identity and community and that some restitution is in order because of the questionable legitimacy of the establishment event.

Given the ties between identity and property claims under customary tenure systems, in 2007, the United Nations recognized the particular property rights of Indigenous peoples in The Declaration on the Rights of Indigenous Peoples [7]. While the Declaration does not attempt to define who is Indigenous, it argues for a definition of land as attached to "cultural identity." In Article 8.1, the Declaration addresses restitution noting, "States shall provide effective mechanisms for prevention of, and redress for: (a) Any action which has the aim or effect of depriving them of their integrity as distinct peoples, or of their cultural values or ethnic identities; (b) Any action which has the aim or effect of dispossessing them of their lands, territories or resources." This recent call for state recognition of Indigenous claims as legitimate (an alternative establishment event) contrasts starkly to the earlier common state practice of removing Indigenous peoples from their territories, in which anterior land claims, often collective, went unrecognized in favor of statutory property systems based on the establishment event of colonization.

Under the Declaration of the Rights of Indigenous Peoples, the first possession of Indigenous peoples, indeed, even their recognition as such, gives them claims to property that migrants and outsiders purchasing the land clearly do not have. This exemplifies the importance of first possession claims. In this instance, contra Locke, first possession claims are based on group membership and identity (whether defined internally by Indigenous groups or by states), rather than on the use of land. These aspects are often considered in common property theory as well.

The most recent international agreement to address land restitution in post-conflict settings is the awkwardly named "Voluntary Guidelines on the Responsible Governance of Tenure of Land, Fisheries and Forests in the Context of National Food Security," referred to here as the Voluntary Guidelines. The Voluntary Guidelines were adopted in 2012 after a wide consultative process led by the FAO Committee on World Food Security. They address land governance and resource access in all contexts (not just post-conflict) and are useful in settings with customary law and customary land tenure. The Voluntary Guidelines directly address land restitution in customary tenure systems. However, they assume that the winners and losers are easily identifiable by the state; that there are 'competent national authorities'; and that restitution of property loss is the overarching goal. Article 14.2 notes: "Where possible, the original parcels or holdings should be returned to those who suffered the loss, or their heirs, by resolution of the competent national authorities. Where the original parcel or holding cannot be returned, States should provide prompt and just compensation in the form of money and/or alternative parcels or holdings, ensuring equitable treatment of all affected people" [8]. In other words, they assume that there is some agreement on what the appropriate establishment event is and, therefore, who has the original, and most rightful claim.

\section{Customary Consideration in Land Restitution}

State recognition of a legitimate role for customary systems in land administration has been increasing and also selective, but this international trend undergirds the recent incidences of land restitution worldwide. Where customary land systems predominate-a common reality of rural areas 
worldwide-formal land restitution processes including compensation, allocation, and redistribution will necessarily engage customary systems, which include both norms and individual authorities. Recent decades have seen a global resurgence in the recognition of customary systems in land administration. A landmark 2003 paper indicated a significant reversal of previous World Bank policy which had considered existing customary and collective landholding systems inferior to individualized freehold titles [9]. Acknowledging that decades of land titling efforts had done little to increase tenure security ([8] p. 39), the report promoted state recognition of group rights (31) and building on customary systems rather than replacing them (62). Recently, The World Bank has supported "fit for purpose" land administration systems as affordable for citizens and environmentally appropriate, a position that illustrates the global pivot toward including customary systems in national land governance. Attention to communal land recognition and titling has seen a recent increase across Southeast Asia, sometimes legally tied to reified notions of indigeneity or subject to acceptance of state land/forest ownership with rights to allocate for communal management [10,11].

Where states seek to recognize customary norms, customary landholding is often cited for its interpretive complexity. Scholars have attributed multiple characteristics to customary systems' relative opaqueness or illegibility to outside entities: negotiable, indeterminate, mutable, manipulatable, context-specific, fuzzy, and prone to reinvention or reinterpretation [12-15]. Qualities of customary systems that defy standardization on a national scale and can be inscrutable to states include intra-regional variability, dependence on localized insider knowledge, adjudication by hereditary or place-based authorities, resource- and site-specific rules, and land ownership's close relationship to factors like ancestry, differential status, and group belonging. Customary land systems excluded from national land systems were deemed not amenable to integration with statutory land law or administration systems that seek "purportedly simple" bright-line rules of possession ([16] p. 338). However, it is at the point of considering land restitution that the sometimes hidden complexities of statutory systems based on possession emerge. Through detailed analysis of an East Timorese community's recurrent displacement and multiple forced relocations, Fitzpatrick and McWilliam note that "simple legal rules may accrue interpretive complexity as they traverse various communicative, epistemic, and enforcement settings" ([16] p. 316). Moreover, original customary claims, colonization, war, displacement, infrastructure development, and new land administration systems all present different potential establishment events or different possible occasions for 'bright-line' rules of possession [17].

Fitzpatrick and Barnes [1] posit that the interpretively complex customary principles of land possession came about to avoid land conflicts and to maintain social order by providing peaceable means to incorporate in-migrants and late arrivals. This stands in contrast to a primary objective of transactional efficiency or clarifying boundaries-as early Western property theories foundational for civil legal codes would posit. Statutory and customary systems carrying "competing sources of possessory entitlement" exist in relationship, and a state seeking standardized land legislation risks destabilizing robust customary property mechanisms that might otherwise be adequate for its social ordering purpose ([1] p. 129). Many studies on Timorese land dispute resolution practices point to an overwhelming preference for using customary systems wherever possible, among both women and men [18-20]. In Timor-Leste, it seems neither possible nor preferred to entirely supplant the customary land processes that are based on precedence.

\section{Precedence in Austronesia}

Precedence is a foundational group identity concept related to land claims throughout the Austronesian world that spans Madagascar across mainland and insular Southeast Asia to the South Pacific. It "describes a concatenation of relationships where the relative status of any person or group is conceptualised and defined by reference to their proximity to a common point of derivation or 'origin'" ([21] p. 23). It is applicable to groups and extended sets of relationships; its political complexity is evident across centuries [22]. Descent from mythical origin sources confers place-based authority 
to groups over given domains. These groups, and others with relatively direct connections to such authorities, often have enduring ritual, political, or military power in the customary realm to this day. Batterbury et al. note that this affects "sense of place, of social, cultural and ecological identity, and rights and obligations to land, water, forest or other local resources" ([23] p. 5).

Precedence often, but not always, confers legitimacy with regard to land claims within a given area. It brings distinctive status and symbolic capital. In contexts of sociopolitical upheaval, precedence-based land claims may have special prominence, resilience, or durability for the highly valued social ordering capacity that they confer [12]. Operative at different social levels, the critical features of precedence as a metaphorical expression of social hierarchy include categorical asymmetry and the possibility of category reversal $[24,25]$. This means that groups are understood to have unequal relationships to other groups (e.g., older/younger, inside/outside, trunk/tip [of branch] where relative proximity to origin confers status), but that these relational classifications have the potential to invert or to reverse in situations of wrong-doing, ritual alliance, migration, or other means.

Importantly, inherent in precedence is the principle that property is relationally and spatially contingent: it matters greatly where one is situated in relation to others. In Austronesian societies, land claims are both socially and geographically marked; lineage and ancestry are important, but relationships to particular, specific, and named places are also critical in bolstering the legitimacy of one's authority over land [26]. Origin narratives contain long strings of place names that outline ancestral itineraries, making the settlement order of resident lineages public to hearers, and containing markers to associated stories or explanations of their relationships to expelled or conquered groups, as well as those that they assimilated. It is important that these relationships and their associated positionality are public and spoken; land authority and ownership have a certain order to them that is widely and commonly known to both landowning and in-migrant groups who reside in a region.

Pathways to inclusion and land access for newcomers and later arrivals exist through various means of ritualized relationship and alliance. ${ }^{1}$ Within the concept of precedence, incorporating outsiders, late-comers, and non-members occurs through arrangements by which conflict is avoided while usually maintaining the landholding groups' precedence. These include intermarriage, outsiders' formal requesting and granting of permission to farm by designated customary authorities (not from individual land-holding families), and non-members' payment of tribute to the anterior, land-holding groups.

In Timor-Leste, as elsewhere in Austronesia, landscape knowledge is linked to facility in communicating with emplaced spiritual entities. This relationship affects the strength and durability of land claims in customary land systems involving precedence. Autochthones, residents with anterior claims, and especially, those with mythical or supernatural attachments to defined domains, tend to have stronger claims, while access rights to land of in-migrants and newcomers tend to be weaker, lesser, limited, or temporary in nature $[16,21,28]$. Proximity to ancestors makes people of certain lineages "privileged intermediaries" between the natural and spirit worlds ([21] p. 38). Given the importance of names in the process of claiming and proving one's claim to land, members of early settlers' descent groups who named features in the physical landscape-often intertwined with ancestral settlement journey narratives-and made initial use of an area's natural resources can have a distinctive, unmatchable advantage over others in claim-making. As the new state of Timor-Leste considered restitution for those who experienced loss—of land and of its associated spiritual connections-through recent decades of forced displacement, it needed to consider legitimacy and potential legal recognition of customary claims, as illustrated in the cases below.

1 Hall et al. [27] argue that all property owners have an interest in exclusion and that exclusion complements access. There are a variety of ways in which exclusion occurs (the market, regulation, or violence) and is legitimated. 


\section{Customary Narratives on Precedence, Possession, and Authority from Oecusse, Timor}

Two mythical origin stories from Timor-Leste's Oecusse-Ambeno enclave illustrate various facets of precedence, the claim-making process, legitimacy, and authority discussed here. ${ }^{2}$

\subsection{Dividing Domains and Authorities}

The first narrative began by recounting how the youngest of four brothers, the indigenous king (usif) of Ambeno, came to have a domain under his authority when Western Timor's land was originally divided. The later arrival of a part-European trader-cum-king rose to authority through processes including (customarily accepted) in-marriage to the indigenous king's daughters and alliance with colonial Portuguese powers. He is also credited with bringing the oft-mentioned hallmarks of "civilization": Catholic religion, fire to cook food, and education. Today, both kingly lineages retain disparate but widely recognized customary authority among Oecusse residents, and bear ultimate responsibility to adjudicate on matters of land, including internal disputes and external borders. ${ }^{3}$ Typical of Timorese narratives, the account incorporates events spanning four centuries, presented in non-linear time sequencing. The Ambeno king selected eighteen or nineteen men, and gave each a domain to rule that had named boundaries, along with ceremonial objects to symbolize their authority granted by the king. These were known as naijuf, a word related to lord (nai), land (nain, naija(n)), and uf (trunk, origin). The narrative continues, recounting the appointment of autochthonous ritual figures called tobe:

Then the population grew and the tasks became too burdensome. So every naijuf asked the king, Who will help us in carrying out rituals and in bringing food and tribute to the king? So the king called the naijuf again to divide their tasks to one person as an implementer, that is, the tobe. With this division of tasks, each naijuf and the people said, If we are each to divide our tasks with a person called a tobe, it is better that each naijuf choose the person himself, because we must choose the correct person whose ancestors have lived there since before [we came], and who can communicate with nature and with the ancestors. And the king agreed.... After the selection, the king said that each year, the naijuf and the tobe that he had recognized had to take food to both the ... kings, to ensure rain and productive harvests... The tasks of the tobe are to take beeswax and cotton wick to the kings' residence(s) to use in church, to ritually control and to oversee sandalwood harvest and beeswax gathering, to protect nature and to communicate with nature, to ask for rain, to reduce the sun's heat, and to reduce high winds.

$\cdots$

So the origin of the tobe and the naijuf is that the king chose them and gave them each their power. Sometimes we hear that the tobe has supernatural origins. ${ }^{4}$ This is true, and when the tobe was chosen by the king, the elders, and families together with the naijuf, they were the ones who chose those people as tobes, because before there were orders from the king, their ancestors already lived in that location, and he was already very accustomed to the communication between people and nature. The naijuf [was also] chosen by the king to control an area.

The above section narrates the order of how customary leadership roles ruling the nested domains of kings (usif), naijuf, and tobe came to be: it emphasizes the importance of subsidiary authority being directly granted by the highest figure of the original settler, the Ambeno king. The autochthonous

2 Oecusse-Ambeno is an enclave district of the nation of Timor-Leste; it is located on the northwestern coast of the island and is surrounded by the Indonesian province of West Timor.

3 For example, in 2017 an agreement by customary authorities at the usif level on the Indonesian and Timor-Leste international boundary preceded boundary demarcation activities by state officials of both nations.

4 In several villages, one of the primary tobe is credited with supernatural origin and the ability to transform himself into other objects, including stones and animals, which adds to his credibility as closely linked to that land. 
qualifications of the tobe concern the place-specificity of interaction with spirits/ancestors and the natural world to ensure productivity, and of rituals needed to avoid irregular or catastrophic weather events. The customary positions of naijuf, who serves in an outward-facing political role representing a village, and of tobe, as the inward-facing ritual leader, still exist in each of the eighteen villages of Oecusse, and most remain active in decision-making with respect to land. Up to the present, strict customary norms govern who may speak on matters of land and in what contexts such speech is permitted. Even today, many tobe rarely leave their assigned domains, and traditionally, they have been separated from association with external influences even from childhood by not being baptized Catholic or attending school. Most villages have multiple tobe who divide their tasks either by duties within the village or by well-defined named geographic domains nested within the naijuf domain, and many villages now have more than one naijuf. Multiple individuals in a role are often defined in relational terms of young/old or great/minor, designations which are common across Austronesia and reflect typical categories of precedence. It is notable that while political changes may affect the relative power of a naijuf, the tobe's identity or authority is very rarely in dispute, because it is deemed to be partially derived from nature.

\subsection{Displacement in Origin Myths and Creating Temporary Settlers}

Displacement is commonly present in origin myths. An abbreviated excerpt from the second origin narrative for one highland village in Eastern Oecusse proceeds as follows, told from the perspective of current residents about their village settlement: ${ }^{5}$

Long ago, there were only a few people here, but the Ambeno king told our tobe-naijuf ancestors to go attack the people who were then living in the area. So the tobe and naijuf and the people attacked these enemies and won, and the former inhabitants left because a lot of them had been killed. When they had all fled, there was still one person left hiding in a tree, who also cooked and ate up in the tree. After our ancestors won, they went back to report to the king that the area had been cleared of enemies, but at night the king himself looked up and saw a fire burning in a tree, and asked, 'Whose fire is that burning in the tree?' The people answered, 'We don't know.' So the king ordered the people to go again to find the person building the fire, and when they did it wasn't a person at all, but a civet cat making the fire. The people caught it to question it, but once it was captured, it was no longer a civet cat but a person, so he answered them: 'Do not kill me, because I guard and control this area.' So the people did not kill him, and he alone was left alive after the other enemies had been killed or fled from this area. So that person originated from the animal, from nature, and the people made him the minor tobe 6 because he knew how to communicate very well with the spirits in the area. However, our ancestors conducted rituals to ensure that he would not have many descendants who might chase us out in return; indeed, the minor tobe never has more than one son, usually born when he is already old.

This account demonstrates that the current village residents do not claim to be first settlers on uninhabited land or pristine forests. Rather, they forcibly cleared their presently claimed village of former inhabitants, save one who was afforded special customary authority in recognition of his autochthony; similar near-elimination of former inhabitants occurs in other origin stories across Timor [29]. Thus, we see in customary tenure systems the idea that there might be multiple legitimate establishment events that confer land authority. The individual designated as the village's minor tobe is known to all, and this role still persists to this day to grant access to cultivate land and to use forests, in addition to conducting agricultural rituals on behalf of the entire village. Notably, the customary hierarchies and distinct roles are enduring, and resident groups that acknowledge their

5 This narrative is excerpted with permission from [28].

6 In this village's (naijuf's domain) case, the "minor" tobe actually holds ritually higher status than the great tobe. Tobe designations are village-specific and highly variable across Oecusse. 
own in-migrant status take measures — with practical effects until the present day - to maintain their earned supremacy as landholders. The narration continued with accounts of how ordinary people's durable land claims came about through labor investment of making swidden gardens, with mention of how land allocations were decided by the ritual figure of the (non-autochthonous) great tobe.

In this war, the people of our area were successful in the struggle for land, so they settled it and made gardens [swiddens]. The great tobe was chosen by the king and naijuf to control the largest land area, because he had a large family and they lost the most people during the battle. The old naijuf was also there before other people came. Later, it was the naijuf and the great tobe who chose the [autochthonous] minor tobe and gave him his domain. Then both tobe received more newcomers [refugees from conflicts], and those people followed the activities of each tobe in his domain. Land belonged to the person who opened a garden there, and their descendants, who divided up the various locations they inherited from their father, until our area was filled with fallowed garden sites. Each family may own many seimu [claimed land area used for agriculture], but separated in different locations. All landowners also received land in the tobe domains.

It is clear that the earliest settlers held the premier customary positions, but some later settlers were also received and incorporated into the descent groups with heritable land. Today, the landholdings of the various resident lineages have a patchwork pattern across the landscape; one can traverse the hills on foot for hours and periodically ask whose land is underfoot, and any local resident can answer that simple question.

However, many multi-generational village residents are not landholders. From other accounts and analyses, it appears that many residents arriving after the beginning of the twentieth century-for example, a cluster of highland families who took refuge in this village from nearby colonial border conflicts around 1910-have never been accepted as having heritable agricultural land without having marriage alliances, although they have lived and farmed on borrowed land in the village for over a century [28]. On Timor's eastern tip, villagers similarly refer to people forcibly relocated to others' customary domains during the 1975-1999 Indonesian occupation as "passengers" or "refugees," emphasizing the temporary nature of displaced peoples who were reluctantly accommodated under duress but for whom "these processes of adjustment and adaptation have not extended to offering heritable land entitlements" without the requisite kinship affiliations ([16] p. 327). Importantly, this Oecusse case indicates that such temporary status can endure for several generations and under different political regimes and realities. These claims have proven resilient and durable; when nearly all of Oecusse's population fled the district in the violence accompanying Indonesia's 1999 departure from Timor-Leste, most returned within a year to their pre-evacuation homesteads and same status with regard to landowning.

These narratives remind us that customary land claims are not static or fixed to which external disruptions occur as a novelty; rather, conflict, incorporation of outsiders, and population fluctuations can be integral to what people recognize as the origin stories that underlie today's customary land claims. These accounts contain aspects of growth and flexibility; new authorities are added as necessary or when new opportunities arise. Customary systems of landholding, like statutory land law, did and do not evolve in a vacuum, but in response to the changing political, social, and agricultural realities in the region. Nevertheless: although accounting for growth and change, origin group claims are what we call here "establishment events" that retain their widely recognized legitimacy for determining a socially accepted baseline for landownership.

Following a major political change, older authority models or patterns may reappear and regain popularity, out of a search for stability, reconfiguring legitimacy, or opportunism of those who were displaced $[17,29]$. Changes in authority provide opportunities for the reconsideration of establishment events and the possibility of land restitution through a recognition of alternative claims. In the first few years after Timor-Leste's 1999 independence from Indonesia, the Timor-Leste state agencies in 
Oecusse formally devolved a great deal of power to the customary authorities $[30,31] .{ }^{7}$ This extended the nascent government's shoestring operation, and was a deliberate attempt by the new state to rebuild national identity in honoring indigenous institutions that had been deprecated and supplanted by government officials during the era of Indonesian occupation. Central government enthusiasm for devolving power to customary land authorities has now waned in comparison to those early post-independence years, and a centralized cadaster has been recently declared essential for national development [32] — signaling a state initiative to establish an "establishment baseline". We now consider our second case.

\section{Creating a New "Establishment Event": Civil Society and National Land Law}

In June 2017, Timor-Leste's President enacted Law No. 13/2017, culminating a protracted fifteen-year process to develop a foundational land law for the new nation [33]. Upon full independence in 2002, Timor-Leste had to grapple with a layered history of Portuguese colonization until 1975, brutal Indonesian occupation (1975-1999) during which much of the population was forcibly displaced for control and surveillance purposes, and a period under transitional UN administration (1999-2002). Political leaders, courts, and civil society faced complex decisions over recognizing land titles issued by former regimes, dealing with ownership and compensation around imposed constructions or agricultural investments, and grappling with conflicts where people returned to their ancestral lands now settled by other displaced people [34]. Timor-Leste experienced strong international pressure and funding to develop land laws that would clarify ownership, facilitate national land transactions, and be amenable to foreign investment [35-38].

Under the transitional UN administration, Timorese leaders made a clear, early decision to defer major decisions on land policy, law, and administration until the government was controlled by East Timorese citizens ([38] p. 5, [39]). Given the high prevalence of internal forced displacement throughout the Indonesian era and massive infrastructure destruction from its violent end in 1999, the question of land restitution was a particularly sensitive political issue. The socio-political uncertainty over relative legitimacy of land titles issued by previous regimes was fraught since past land titles followed political loyalties and favor. Technical and political issues around titles contributed to the extended delay in promulgating a national land law. Debates over the relatively small area of previously titled land, however, also served to distract attention from the core issues of consistent concern to the rural agrarian majority of East Timorese: fear of land appropriation by the state and uncertain protection for the majority of rural landholding that operates under customary mechanisms $[19,36,40]$. With the Indonesian land statutes suspended since 1999, Timor-Leste went without the basic legal scaffolding for land administration until 2017.

Addressing the new nation's land law lacuna became a priority for external agencies [41]. In the early 2000s, a USAID-funded program drafted several pieces of legislation that protected inherited state property from individual claims and established processes for renting state land [35,42]. A subsequent USAID program (Ita Nia Rai) sought to develop a large-scale mechanism for registering land claims, addressing disputes, and supporting legislation for land titling. In 2008, this program supported an advisor to draft a more comprehensive land law [43], beginning a convoluted process of legal drafts and revisions that was to continue for nine years [44,45]. From 2009, there were multiple versions released, circulated, and redrafted by the Ministry of Justice; government-led consultations held in response to intensive 2009 lobbying by civil society organizations (CSOs); CSO-led community consultations from 2010 that demonstrated widespread fear of land expropriation by the state [46]; Parliamentary approval, followed by Presidential veto in 2012 for which the CSO land network Rede ba Rai strongly lobbied; and extended debates of a "transitional land law" in Parliament prompting more

7 This went beyond rhetoric; in some cases, the government even paid fines to village authorities for violating the customary norms they set on natural resource protection. 
revisions. In February 2017, what many have called the long-awaited "first" land law (No. 13/2017) was unanimously approved by the National Parliament and enacted by the President in June 2017. Related and subsequent legislation remains under development [47-49].

Why the protracted process in passing this legislation? Timor-Leste's post-conflict and recovery context, the special complexity of multi-layered claims, and expected effects of running new legal and governance institutions are important factors. However, passing the new land legislation was deemed particularly weighty because it would be setting a new "establishment event" on an issue of critical national importance. The process was extended in part because local communities, international advisors and scholars, and CSOs persistently raised critical matters to governing authorities, prompting multiple revisions of draft laws [19,40,44-46,50,51]. Rural villagers, government officials, rights-focused local non-governmental organizations (NGOs), and involved academics were all keenly aware of the profound importance of the process. Fitzpatrick and McWilliam suggested that in order to avoid enacting an unenforceable law, a "politico-legal community must form around common points of epistemic reference" with respect to property and ownership ([16] p. 339).

Civil society had a key role in coordinating action with regard to the land law debate that proceeded through multiple elections and government changes. Following independence, multiple NGOs and CSOs actively pursued community understandings and preferences regarding landholding, commissioning research and hosting broad community consultations nationwide [18,36,46,52,53]. Mobilized by the 2008-2009 policy and legal drafts, "civil society advocates argued that these policy options did not reflect Timor-Leste cultural understandings of land, that given the importance and fundamental nature of land in Timor-Leste, land laws should be based on a broadly consultative land policy" ([44] p. 4). Local organizations progressively joined to expand Rede ba Rai (Land Network, in the official national language Tetum), which in mid-2019 has twenty-four institutional members, including the most prominent national NGOs spanning legal rights, women's groups, development and judicial system monitoring, and environmental sustainability. ${ }^{8}$

Questions of state vs. customary ownership of rural land and eviction of forcibly displaced citizens were central in civil society responses during the land law debates. As noted above, and similar to other regional customary land systems, Timorese land ownership and access are inseparable from issues of group identity that are socially ordered by principles of precedence. For this reason, it proved impossible for Western legal frameworks to be locally accepted without engaging how group identity intersects with belonging to particular places related to ancestors, sociocultural traditions, and collective economic practices $[1,16,36]$. Communal land rights, the authority of customary leaders, and the spiritual and cultural identity purposes of land formed common threads of Rede ba Rai's strategy, activities, and communications [58]. Notably, while Rede ba Rai supported the role of customary authorities (including advocating for a presumption that customary processes be recognized as operative in rural areas), they also advocated for gender equity in land ownership and land rights for displaced people, two areas which might be at odds with some Timorese customary systems [19]. The final version of the 2017 law was a compromise. It does not afford landholding protection to people currently occupying land onto which they were forcibly displaced (No. 13/2017, Article 20.2), and it offers only weak, untried protection unexplored in community consultation for customary land, alongside non-specific protection against eviction [59].

The most prominent Timorese conversation on 'indigeneity' does not reflect processes elsewhere in Southeast Asia where externally imposed categorization and/or self-identification as Indigenous have been contraposed with other national social groupings in pursuit of customary land recognition [10,11,60-62]. To date, Timor-Leste largely follows the still widespread discourse in the region that citizens are equally indigenous; ethnic distinctions are not made with respect to

8 The network promotes community awareness and input into political and legal processes related to land governance, rights, and access, and provided feedback to the national government on successive drafts of the proposed land law [54-57]. 
national land rights, though recent or direct (colonial) Portuguese ancestry remains an important social marker. Timor-Leste is still actively creating a national identity, markedly separate from its recent occupier Indonesia, linked in complex ways to national unity and to a sense of belonging to the land. In the nation's first two decades, much internal jockeying for status has revolved around past political involvement in the national resistance movement; mentions of "indigenous" are reserved for the colonial-era differentiation of Timorese from Europeans [63,64]. Notably, identity formation has sometimes embraced colonial distinctions of Timor-Leste as foundational, such as the national President's description of Timor-Leste as distinctly Portuguese and Catholic, in notable contrast to the Dutch colonial and Muslim or Protestant aspects of Indonesia ([65] p. 90). Public debates on land legislation have more space ahead to grapple with the particular definitions, bounds, and intranational variations in what constitutes "customary" understanding and practice in Timor-Leste.

\section{Discussion and Conclusions: Precedence, Possession, and Land Restitution}

At first glance, the Western concept of original acquisition and the Austronesian understanding and practice of precedence seem analogous. Both concepts establish relational priority in land ownership and convey legitimacy in land claims. Both lend clarity to what counts as an "establishment event" for legitimate land claims. Understanding the nature of legitimate "first" claims is critical to discussions of land restitution, as restitution often contests or interrogates the legitimacy of "first" claims. In this conclusion, we reflect on the above cases to consider what customary practices of precedence bring into relief regarding the Western concept of first possession. We discuss five relevant areas of intersection.

(1) Legitimate sources of land authority

Within the Timorese concept of precedence, authority over land domains is set by both arrival and affiliation. Origin groups are widely accepted as legitimate arbiters of land concerns, and there are established, but limited, means to incorporate newcomers in processes that are inherently relational. Ultimate land authority is relatively uncontested within systems of precedence because it sets the foundational reference point of mythical origin stories-even when it involves eviction or elimination of prior inhabitants. Origin stories contain narrations of legitimate authority. In some cases, customary land authority has proven more resilient to successive political disruptions than statutory law [12].

Although statutory law is sometimes considered more rigid than customary systems, Western concepts of "first" possession and occupation are also malleable. As we have noted elsewhere, the post-conflict land claim process is highly politicized, contingent on authority, and subject to accrual and fading over time [66]. Major sociopolitical transitions are often moments where societies come to recognize new "establishment events," to which (later) land restitution processes may refer-for example, migration, colonizing settlement, or the onset of a new governance regime. When this occurs, re-establishing and reshaping land systems, including land restitution, is contingent on whether claimants legitimize the authority of potential decision-makers regarding their land, and whether they exercise the power to enforce their recognition $[13,67]$.

Timor-Leste's protracted land law process contained several critical points of contention over legitimacy of land authority. Newly independent East Timorese leaders chose to defer land law and policy until the government was under their control, signaling a preference for land matters to be decided by citizens rather than foreigners. A significant part of civil society's persistent response to successive draft land laws was that legislation needed to account for Indigenous conceptualizations of land, which are inextricably linked to identity and attendant customary systems. The media release announcing the enactment of the 2017 land law concludes by noting that "the Government was determined to see this law presented, passed and promulgated before the end of its mandate" ([33] p. 1). Previous governments had made similarly strong attempts without success, and so passage of land legislation also became a means to establish authority and legitimacy for incumbent officials: projecting legitimate authority of the new state externally, and also garnering domestic credit for political effectiveness. 
(2) Arbitrary establishment dates or foundational events

It is worth paying close attention to the timing of events that mark transition points in landholding. The 1910 cut-off period for the Oecusse village's "refugee" in-migrants (who did not establish marriage relationships; see page 8 above) to gain landholding status may seem arbitrary. However, this phenomenon occurs in statute law as well. The 2016 "transitional" land law draft stated that the law would protect the rights of people residing on land before 30 December 1998-before a new round of displacement occurred surrounding the August 1999 referendum that resulted in independence and Indonesia's turbulent departure from Timor-Leste. Setting that particular date as the marker conveyed protection of residential rights of displaced Timorese who remained in the assigned locations (usually distant from their origin areas) where the Indonesian military forcibly resettled them, mostly in the late 1970s and early 1980s. However, this reference was removed from the final 2017 law, which may ultimately favor the prior ancestral/origin land claims that conflict with the residential realities of other communities resettled on that land for two decades.

As Rede ba Rai reminded Timorese legislators of non-economic values of land, precedence can remind us of the contingent and arbitrary nature inherent in first possession. Classic "order without law" or "spontaneous order" examples in Western law include examples of digging tools left in California goldfield holes or first harpoon strikes on whales [1], as well as the ability of communities to resolve land conflicts outside of the legal sphere [68]. However, these examples neglect prior, potentially Indigenous claims to particular land or sea domains or the creatures therein-either for economic use, or for non-economic purposes including preservation as sacred spaces. At the heart of many land restitution cases is contention over what multiple parties recognize as the foundational or establishment event whether it be "first arrival," colonization, or victory in war. Clearly, disagreements over states' override of Indigenous claims is ubiquitous in Western settler society contexts, but similar forms of contestation are also evident after violent conflicts that change authority structures and even in seemingly mundane processes of drafting land legislation.

(3) Privileging of social order

First possession may not be enforced absolutely. Other highly valued considerations, including social order, current norms of equity, and international pressure may outweigh an idealized implementation of a formal property norm that aims to be clear or simple. In an important analysis of the operation of early legal decisions and practice regarding land in Timor-Leste, Almeida notes that de facto implementation reflects a blend of responsible individuals' familiarity with Portuguese or Indonesian land law or administration, irregular enforcement, and some degree of elite pressure regarding particular properties [69].

Land claimants constantly make choices in how they will relate to existing and new land authorities. As in the second Oecusse narrative above, even in the pre-colonial times or in regions beyond reach of any state, in-migrants and those fleeing conflict had to align with some existing authorities: Then both tobe received more newcomers ["refugees"], and those people followed the activities of each tobe in his domain. In the Austronesian world, origin stories are interwoven with aspects of disruption, mobility, and displacement, and intertwined with features including colonialism, outsider arrivals, vagaries of trade, and both inter- and intra-group intrigues. Kammen documents and chronicles the recurrent violently contested authority and consequent realignments over the course of three centuries in Central Northern Timor [70].

Many Timorese origin narratives do not convey an "original" state of unsettled land, first and peacefully inhabited by one's ancestors, but include-or begin-with expulsion, extirpation, or disappearance of the original or prior inhabitants. The Oecusse origin myth, on which they base their land claims and customary authority systems, begins with conquering and emptying the land of others. Ancestors and political leaders (as in the second king) are revered for bringing order, both social and spiritual, not (only) for first possession of land. In this case, the establishment event is not first claim to the land, but the creation of social and spiritual order. This is also the case for customary leaders, such 
as the part-European king above whose arrival and growth of power-which eventually amounted to "regime change" in Oecusse-Ambeno-is believed to have ushered in elements of sociocultural improvement. Similar stories and attendant justification for coming to power are found throughout the region. In origin narratives which bear practical consequences for modern landholding, the capacity to order subsequent social relations may supplant prior rights of first possession.

\section{(4) Recognition of spiritual ties to land}

In some situations where land claims are related to supernatural phenomena, ancestral or early claims to land and/or authority may be more persistent than other kinds of claims. Austronesian ideas of first possession entail a facility in communicating with emplaced spirits of the land. In the Oecusse narrative above, first possession (of the one remaining individual seen to be cooking in a tree) is distinctive and it cannot be fully supplanted by newcomers or competing systems without risk, even though his (the minor tobe's) people were defeated and driven out. In Timor-Leste, it is commonly understood that lack of attention or inappropriate action regarding spirits of place can lead to sickness, death, and other forms or evidence of disordered relationships; modernization programs can receive the same blame or consequences as individual actors [71]. For this reason, the emplaced nature of customary roles, particularly that of the tobe, is an important consideration in matters of competing or contested authority. It is remarkable that amidst widespread political turbulence in Timor-Leste, the proper lineage of who should be the tobe in Oecusse villages was never in dispute. By contrast, a few naijuf were involved in national political movements, and as a result, left Timor-Leste; in some cases, his role was transferred to another man in the same lineage. Customary land authority is spatially bounded and tied to location; it is not transferable to another location, giving displaced people an incentive to return in order to reclaim authority, as well as property, lost through displacement. This element has clear implications in land restitution as, contra the 'Voluntary Guidelines' (see final paragraph of Section 3), allocating land in a different location may not be acceptable.

(5) The possibility of reversal

Customary systems, like states, can gain and lose legitimacy through various means. Customary leaders' close association with governing powers or other forces (e.g., commercial entities, religious movements, or political parties) can serve to bolster their power, sometimes temporarily. This was the colonial states' strategy with techniques of indirect rule, to appoint existing customary leaders as agents of the state [72-74]. Origin stories which demonstrate the concept of precedence also include these elements of change through affiliation. An origin group may devolve a position of authority to others, bringing them into the customary hierarchy; they may also grant domains to newcomers through established norms. Transgressions or losses in political and ritual realms can reverse or nullify origin group authority. Precedence reminds us that the capacity for categorical reversal of authority has its analogies in property relationships, both customary and formal/legal.

In conclusion, we find that examining origin story narratives alongside accounts of legal formation blurs an oft-presumed absolute distinction between customary and statutory processes. Characteristics of the Austronesian concept of precedence carry important reminders about Western property norms of first possession. These intersections are especially instructive where the relative, and changing, recognized legitimacy of establishment events often forms the core impetus for land restitution. While we often think of establishment events as being in the past, events like first occupation or colonization. In this paper, we point out that establishment events can and do occur in the contemporary era, particularly in post-conflict settings in which new rules are made as to which land rights will be recognized [66]. Additionally, these concepts may be applicable to countries that may not have experienced war but are resetting their property systems because of changes in sovereignty, such as post-Soviet states shifting from socially owned to private property. This theorizing regarding establishment events is applicable across a variety of circumstances in which rights to housing, land and property are ignored or re-asserted in land restitution processes and the establishment of new land laws. 
Author Contributions: This is the second article on post-conflict property rights that we have co-authored (see S.F.J. and L.S.M.Y. 2016 [66]). We both developed the original concept and refined the argument for this paper. S.F.J. drafted sections on Western property law and international agreements. L.S.M.Y. drafted sections on precedence, the case studies from Timor-Leste, and the Discussion and Conclusions. Both authors participated in responses to reviewers.

Funding: The corresponding author's research was funded in part by a John Stott research excellence grant in Human Needs and Global Resources.

Acknowledgments: We are grateful for the Timorese customary authorities, friends, and neighbors of Oecusse who shared their lives and their narratives that inspired this paper; we hope that this paper honors their understanding and practice of landholding. The authors extend thanks to Kathryn Alexander, Amy Reynolds, Meabh Cryan and three anonymous reviewers for formative comments on an earlier draft. An early version of this paper was initially presented at the 2017 International Association for the Study of the Commons conference.

Conflicts of Interest: The authors declare no conflict of interest.

\section{References}

1. Fitzpatrick, D.; Barnes, S. Rules of Possession Revisited: Property and the Problem of Social Order. Law Soc. Inq. 2014, 39, 127-151. [CrossRef]

2. Locke, J. Two Treatises of Government; Millar, A., Woodfall, H., Whiston, I., White, B., Rivington, I., Davis, L., Reymers, C., Eds.; Awnsham Churchill: London, UK, 1764.

3. Smith, A. Lectures on Jurisprudence; Meek, R.L., Raphael, D.D., Stein, P.G., Liberty Fund, Eds.; Oxford University Press: New York, NY, USA, 1978.

4. Hume, D. An Enquiry Concerning the Principles of Morals, 1912th ed.; Project Gutenberg: Salt Lake City, UT, USA, 1777; Volume 12.

5. Huh, S. Title to Territory in the Post-Colonial Era: Original Title and Terra Nullius in the ICJ Judgments on Cases Concerning Ligitan/Sipadan (2002) and Pedra Branca (2008). Eur. J. Int. Law 2015, 26, 709-725. [CrossRef]

6. Banner, S. Why Terra Nullius? Anthropology and Property Law in Early Australia. Law Hist. Rev. 2010, 23, 95-131. [CrossRef]

7. United Nations. United Nations Declaration on the Rights of Indigenous Peoples. In A/RES/61/295, Assembly; U.N.G., Ed.; United Nations: New York, NY, USA, 2007; Volume A/RES/61/295.

8. Food and Agriculture Organization of the United Nations. Voluntary Guidelines on the Responsible Governance of Tenure of Land, Fisheries and Forests in the Context of National Food Security; Food and Agriculture Organization of the United Nations: Rome, Italy, 2012.

9. Deininger, K. Land Policies for Growth and Poverty Reduction; World Bank: Washington, DC, USA, 2003.

10. Baird, I.G. 'Indigenous Peoples' and land: Comparing communal land titling and its implications in Cambodia and Laos. Asia Pac. Viewp. 2013, 54, 269-281. [CrossRef]

11. Andersen, K.E. Communal Tenure and the Governance of Common Property Resources in Asia: Lessons of Experiences in Selected Countries, Land Tenure Working Paper 20; Food and Agriculture Organization of the United Nations: Rome, Italy, 2011.

12. Fitzpatrick, D.; Barnes, S. The Relative Resilience of Property: First Possession and Order without Law in Timor-Leste. Law Soc. Rev. 2010, 44, 205-238. [CrossRef]

13. Benda-Beckmann, F.V.; Benda-Beckmann, K.V.; Brouwer, A. Changing "indigenous environmental law" in the central Moluccas: Communal regulation and privatization of sasi. Ekonesia 1995, 2, 1-38.

14. Moore, S.F. Social Facts and Fabrications: “Customary" Law on Kilimanjaro, 1880-1980; Cambridge University Press: Cambridge, UK, 1986; p. 397.

15. Berry, S. No Condition Is Permanent: The Social Dynamics of Agrarian Change in Sub-Saharan Africa; University of Wisconsin Press: Madison, WI, USA, 1993.

16. Fitzpatrick, D.; McWilliam, A. Bright-Line Fever: Simple Legal Rules and Complex Property Customs among the Fataluku of Timor-Leste. Law Soc. Rev. 2013, 47,311-343. [CrossRef]

17. Gunter, J. Communal Conflict in Viqueque and the 'Charged' History of '59. Asia Pac. J. Anthr. 2007, 8, 27-41. [CrossRef]

18. Centre of Studies for Peace and Development. Women's Access to Land and Property Rights in the Plural Justice System of Timor-Leste; Centre of Studies for Peace and Development: Dili, Timor-Leste, 2014. 
19. Almeida, B.; Wassel, T. Survey on Access to Land, Tenure Security and Land Conflicts in Timor-Leste; Van Vollenhoven Institute and the Asia Foundation: Leiden, The Netherlands, 2016.

20. Meitzner Yoder, L.S. Custom and conflict: The uses and limitations of traditional systems in addressing rural land disputes in Timor-Leste. In Proceedings of the workshop on Land Policy and Administration for Pro-Poor Rural Growth, Dili, Timor-Leste, December 2003.

21. Barnes, S. Origins, Precedence, and Social Order in the Domain of Ina Ama Beli Darlari. In Land and Life in Timor-Leste: Ethnographic Essays; McWilliam, A., Traube, E.G., Eds.; ANU Press: Canberra, Australia, 2011; pp. 23-46.

22. Hägerdal, H. Rebellions or factionalism? Timorese forms of resistance in an early colonial context, 1650-1769. Bijdragen tot de Taal Land en Volkenkunde 2007, 163, 1-33. [CrossRef]

23. Batterbury, S.P.; Palmer, L.; Reuter, T.; De Carvalho, D.D.A.; Kehi, B.; Cullen, A. Land access and livelihoods in post-conflict Timor-Leste: No magic bullets. Int. J. Commons 2015, 9, 619. [CrossRef]

24. Fox, J.J. The Discourse and Practice of Precedence. In Precedence: Social Differentiation in the Austronesian World; ANU Press: Canberra, Australia, 2009; pp. 91-109.

25. Fox, J.J. Precedence in Perspective. In Precedence: Social Dfferentiation in the Austronesian World; Vischer, M.P., Ed.; ANU Press: Canberra, Australia, 2009; pp. 1-11.

26. McWilliam, A. Paths of Origin, Gates of Life: A Study of Place and Precedence in Southwest Timor; KITLV Press: Leiden, The Netherlands, 2002.

27. Hall, D.; Hirsch, P.; Li, T.M. Powers of Exclusion: Land Dilemmas in Southeast Asia; University of Hawaii Press: Honolulu, HI, USA, 2011.

28. Meitzner Yoder, L.S. Tensions of Tradition: Making and Remaking Claims to Land in the Oecusse Enclave. In Land and Life in Timor-Leste: Ethnographic Essays; ANU Press: Canberra, Australia, 2011; pp. 187-216.

29. McWilliam, A.; Traube, E.G. Land and Life in Timor-Leste: Ethnographic Essays; ANU EPress: Canberra, Australia, 2011.

30. Meitzner Yoder, L.S. Hybridising Justice: State-Customary Interactions over Forest Crime and Punishment in Oecusse, Timor-Leste. Asia Pac. J. Anthr. 2007, 8, 43-57. [CrossRef]

31. Meitzner Yoder, L.S. The tobe and tara bandu: A Post-Independence Renaissance of Forest Regulation Authorities and Practices in Oecusse, Timor-Leste. In Modern Crises and Traditional Strategies: Local Ecological Knowledge in Island Southeast Asia; Ellen, R., Ed.; Berghahn: New York, NY, USA, 2007; pp. 220-237.

32. Government of Timor-Leste. Secretary of State for Land and Property Launches Registry in Baucau; Government of Timor-Leste: Dili, Timor-Leste, 2015.

33. Pereira, A.G. Enactment of Land Law Major Step for Development; República Democrática de Timor-Leste: Dili, Timor-Leste, 2017.

34. Fitzpatrick, D. Land Claims in Timor-Leste; Asia Pacific Press: Oakland, CA, USA, 2002.

35. Urresta, E.; Nixon, R. Report on Research Findings, Policy Options and Recommendations for a Law on Land Rights and Title Restitution; Timor-Leste Land Law Program: Dili, Timor-Leste, 2004.

36. Rede ba Rai. Land Registration and Land Justice in Timor-Leste: Culture, Power and Justice; Haburas Foundation: Dili, Timor-Leste, 2013.

37. Fitzpatrick, D.J. Property Endowments and Social Ordering: The long road to land law in Timor-Leste. In Property and Sovereignty: Legal and Cultural Perspectives; Smith, J.C., Ed.; Ashgate Publishing Limited: Surrey, UK, 2013; pp. 35-58.

38. International Crisis Group. Managing Land Conflict in Timor-Leste; Crisis Group: Dili, Timor-Leste; Brussels, Switzerland, 2010.

39. De-Sousa Xavier, P. Land Rights and Sustainable Development in Timor-Leste. In Proceedings of the Conference on Sustainable Development in Timor-Leste, Dili, Timor-Leste, 25-31 January 2001; pp. 102-103.

40. Fitzpatrick, D.; McWilliam, A.; Barnes, S. Property and Social Resilience in Times of Conflict: Land, Custom and Law in Timor-Leste; Ashgate: London, UK, 2012.

41. Brown, M. Land and Property Administration in Timor-Leste: Summary of the Consultants' Reports Prepared by the Land and Property Administration Project (FS/TIM/00/S01); United Nations Centre for Human Settlements (Habitat): Fukuoka, Japan, 2001. 
42. Urresta, E.; Nixon, R. Report on Research Findings and Policy Recommendations for State Property Administration/Lease of Government and Private Property; Centro Nacional de Investigação Científica, Universidade Nacional Timor Lorosa'e; Direcção de Terras e Propriedades and ARD, Inc.: Dili, Timor-Leste, 18 October 2003; p. 52.

43. Lopes, I. Technical Framework for a Transitional Land Law for Timor-Leste; USAID/ARD Strengthening Property Rights in Timor-Leste Ita Nia Rai Project: Dili, Timor-Leste, 2008.

44. Cryan, M. The Long Haul: Citizen Participation in Timor-Leste Land Policy. State, Society E Governance in Melanesia Discussion Paper; ANU College of Asia and the Pacific: Acton, Australia, 2015.

45. Almeida, B. Land Tenure Legislation in Timor-Leste; Universiteit Leiden Faculty of Law and The Asia Foundation: San Francisco, CA, USA, 2016.

46. Haburas Foundation. Communities Voices on Land: The Results of the Matadalan ba Rai Consultation Process; Haburas Foundation: Dili, Timor-Leste, 2013.

47. Government of Timor-Leste. Levantamento Cadastral De Timor-Leste Chegará A Seis Distritos Até Ao Final De 2014; Government of Timor-Leste: Dili, Timor-Leste, 2014.

48. PM timorense considera essencial resolver problemas da terra para atrair investimento. Saponotícias 22 June 2015. 2015. Available online: http://noticias.sapo.tl/portugues/lusa/artigo/19395005.html (accessed on 21 August 2016).

49. Government of Timor-Leste. SoSLP Launches National Registration System in Aileu; Government of Timor-Leste: Dili, Timor-Leste, 2015.

50. Cryan, M. Whose Land Law? Analysis of the Timor-Leste Transitional Land Law; The Asia Foundation: San Francisco, CA, USA, 2016.

51. Fitzpatrick, D.; McWilliam, A.; Barnes, S. Policy Notes on Customary Land in Timor Leste. 2008. Available online: http://www.mj.gov.tl/files/Policy\%20notes\%20on\%20customary\%20land\%20in\%20Timor\% 20\%20Leste $\% 20 \% 20 \% 20 \% 20 \% 20 \% 20$ Fitzpatrick\%20\%20\%20\%20\%20\%20\%20McWilliam\%20Barnes \% 20Revised\%20November\%202008.pdf (accessed on 16 August 2019).

52. Kadalak Sulimutuk Institute Land Working Group. Sumbangan Pemikiran untuk Reformasi Tanah; Kadalak Sulimutuk Institute Land Working Group: Dili, Timor-Leste, 2001; p. 12.

53. Cryan, M. The Social Functions of Land as Local Knowledge. In Matenek Lokal_-Timor Nian; Carvalho, D., Ed.; UNESCO: Jakarta, Indonesia, 2011; pp. 42-56.

54. Rede be Rai. Rede ba Rai Statement on the Expropriation Law; Fundasaun Haburas Rede ba Rai: DIli, Timor-Leste, 2010.

55. Martins, I.; Costa de Araujo, F.D. Segundu Submisaun Ba Ministeriu Justisa Republika Demoktratika Timor-Leste Husi Rede Ba Rai Relasiona Ho Rejime Espesiál Kona-Bá Definisaun Na'in Ba Bem Imóvel Nian 15 Fevereiru 2013; Rede Ba Rai, Fundasaun Haburas: Dili, Timor-Leste, 2013.

56. Foundation, H. Submisaun Ba Komisaun A, Parlamentu Nasional Husi Rede Ba Rai Kona-Ba Proposta Lei Rejime Especial Ba Definisaun Titularidade Soin Imovel; Haburas Foundation Sekretariadu Rede ba Rai: Dili, Timor-Leste, 8 June 2016.

57. Rede ba Rai. Rede ba Rai husu Prezidente Republika Atu Promulga Pakote Lei ba Rai; Rede ba Rai: Dili, Timor-Leste, 2017.

58. Cryan, M.; Ingram, S.; Kent, L.; McWilliam, A. 'Empty Land'? The Politics of Land in Timor-Leste. In A New Era? Timor-Leste after the UN; ANU Press: Canberra, Australia, 2015.

59. Ferreira, M. The New Land Laws and Their Likely Impact in Rural Areas. In Proceedings of the 2018 Timor-Leste Update, Canberra, Australia, 21-22 June 2018.

60. Lynch, O.J.; Talbott, K. Balancing Acts: Community-Based Forest Management and National Law in Asia and the Pacific; World Resources Institute: Washington, DC, USA, 1995; p. 187.

61. Baird, I. The construction of 'Indigenous Peoples' in Cambodia. In Alterities in Asia: Reflections on Identity and Regionalism; Yew, L., Ed.; Routledge: London, UK, 2011; pp. 155-175.

62. Li, T.M. Articulating Indigenous Identity in Indonesia: Resource Politics and the Tribal Slot. Comp. Stud. Soc. Hist. 2000, 42, 149-179.

63. Kammen, D. Master-Slave, Traitor-Nationalist, Opportunist-Oppressed: Political Metaphors in Timor-Leste. Indonesia 2003, 76, 69-85.

64. Kammen, D. Subordinating Timor: Central authority and the origins of communal identities in Timor-Leste. Bijdr. Taal Land Volkenkd. 2010, 166, 244-269. [CrossRef] 
65. Meitzner Yoder, L.S. Piloting the Experimental ZEESM Megaproject: Performing the Future in the Oecusse-Ambeno Enclave. In The Promise of Prosperity: Visions of the Future in Timor-Leste; ANU Press: Canberra, Australia, 2018; pp. 85-98.

66. Joireman, S.F.; Meitzner Yoder, L.S. A Long Time Gone: Post-conflict Rural Property Restitution under Customary Law. Dev. Chang. 2016, 47, 563-585. [CrossRef]

67. West, H.G. 'This neighbor is not my uncle!': Changing relations of power and authority on the Mueda Plateau. J. South. Afr. Stud. 1998, 24, 141-160. [CrossRef]

68. Ellickson, R. Order without Law; Harvard University Press: Cambridge, MA, USA, 1991.

69. Almeida, B. Navigating without a Compass: State Transition in Timor-Leste's Formal Land Tenure System. In Transformations in Independent Timor-Leste: Dynamics of Social and Cultural Cohabitations; Viegas, S.D.M., Feijó, R.G., Eds.; Routledge, Taylor \& Francis: London, UK; New York, NY, USA, 2017; pp. 123-141.

70. Kammen, D. Three Centuries of Conflict in Timor-Leste; Rutgers University Press: New Brunswick, NJ, USA, 2015.

71. Rose, M. 'Development', Resistance and the Geographies of Affect in Oecussi: Timor-Leste's Special Economic Zone (ZEESM). Singap. J. Trop. Geogr. 2017, 38, 201-215. [CrossRef]

72. Havik, P.J.; Keese, A.; Santos, M. Administration and taxation in former Portuguese Africa, 1900-1945; Cambridge Scholars Publishing: Newcastle Upon Tyne, UK, 2015.

73. Mamdani, M. Citizen and Subject: Contemporary Africa and the Legacy of Late Colonialism; Princeton University Press: Princeton, NJ, USA, 1996; p. 353.

74. Ward, R.G.; Kingdon, E. Land Use and Tenure: Some Comparisons. In Land, Custom and Practice in the South Pacific; Ward, R.G., Kingdon, E., Eds.; Cambridge University Press: Cambridge, MA, USA, 1995; pp. 6-35.

(C) 2019 by the authors. Licensee MDPI, Basel, Switzerland. This article is an open access article distributed under the terms and conditions of the Creative Commons Attribution (CC BY) license (http://creativecommons.org/licenses/by/4.0/). 